\title{
Michael KELLY
}

Southampton University

\section{ISSUES FOR LANGUAGE POLICY IN HIGHER EDUCATION}

\begin{abstract}
Summary. Higher education is in a period of far-reaching changes in Europe, and language programmes are vitally affected by these changes. In addition to language competence development, often in at least two foreign languages, these programmes may provide detailed study of different aspects of societies, such as social and political structures as well as business environment. Every university has adopted a strategy of internationalisation, seeking to attract staff and students from abroad, develop links with institutions in other countries, and raise the international ranking of the university. The situation provides important opportunities but also serious threats. Since policy makers are busy people, they will generally not wish to spend much time in puzzling out the nature of a problem or what they ought to do about it. The aim of this paper is to examine some of the most important issues in language policy for higher education across Europe, and to offer some suggestions about how they might be addressed in practice. In order to achieve the effective development of foreign language competence in higher education, it is important that academic staff should engage with policy makers in order to persuade them of the importance of foreign language competence. These problems need to be addressed to policy makers at a national level, such as ministers and civil servants.
\end{abstract}

Keywords: higher education, issues in language policy, programmes.

\section{The diversity of language programmes}

Languages appear in many varied forms in higher education (Evans, 1988; Phipps and Gonzalez, 2004). Often the same institution has several academic units that carry some responsibility for teaching and research in the area of languages. A preliminary scan of the field reveals several different types of programme, each with its particular history and identity, and each with a specific profile of academic staff, students and stakeholders (Towell, 1998).

At the most specialised end of the languages spectrum, there are different types of language degree, which provide courses for students who will spend all or most of their time studying languages (Evans, 1990). The longest established degree programmes are those which combine the study of language and literature. In many countries these are called Philology degrees, referring to their origins at a time when the principal purpose of studying literature was to deepen the students' understanding of language (Risager, 2006). To a large extent, these degrees were 
introduced at the end of the $19^{\text {th }}$ century and took their pattern from the study of Classics, which focused on a canon of the most esteemed authors. The first focus of literary study was on the use of language (broadly grammar and rhetoric) and this was extended to include literary analysis and to a limited extent the study of social and cultural background. In more recent years, much debate has turned on the extension of the canonical works to include a wider range of writers and to include other cultural forms, especially film (Forbes and Kelly, 1995; Buttjes and Byram, 1991). Many philology degrees involve only one foreign language, though they may in some cases involve two.

More recently established, mainly from the 1960s onwards are degree programmes in applied languages (Hinkel, 1999; Kramsch, 2004). These focus on learning languages with reference to particular social settings (Zhu et al., 2007). They frequently have a strong vocational emphasis, preparing students to work in particular areas of business or the professions. In addition to increasing language competence, often in at least two foreign languages, these programmes may provide detailed study of different aspects of societies, such as social and political structures and the business environment.

Courses in translation and interpreting have been established in some countries since the $17^{\text {th }}$ century, though most of those now active have been established during the $20^{\text {th }}$ century (Roditi, 1982). In some cases, degrees in applied languages include components of interpreting and translating, but the majority of more specialised degrees are postgraduate qualifications, situated in the second cycle of studies. There are relatively small numbers of these courses across Europe, though the number of courses in translation is increasing. The courses are primarily concerned with preparing students to enter employment in the language industries. ${ }^{1}$

Courses in language teacher training take two main forms. They may be integrated into a first cycle degree in philology or applied languages, sometimes with an additional second cycle component. Or they may be a second cycle degree, open to students who have studied a philology or applied languages degree. They generally lead to an officially recognised status as teacher and to employment in school. In many cases, the focus of the course will be on pedagogy, but in some cases it remains focused on philology (Kelly, Grenfell, and Jones, 2003; Richards and Nunan, 1990).

Most universities provide language learning opportunities for their students. ${ }^{2}$ Frequently they take the case of modules which students may follow as part of their programme of study in another subject. They may also be studied as an addition to the degree programme, in which case students may be able to take the

1 More information can be gained from the website of the Conférence Internationale permanente d'Instituts Universitaires de Traducteurs et Interprètes (CIUTI): http://www. ciuti.org/; and the OPTIMALE project, Optimising Translator Training: http://www. translator-training.eu/optimale/index.php.

2 There are useful resources in this area on the website of the European Network for the promotion of Language Learning among all Undergraduates (ENLU): http:// http://www. celelc.org/, click through via 'Projects'. 
course free of charge, or may be required to pay a separate fee. In most cases, modules are provided by a specialist academic unit, such as a Language Centre, which may be associated with a philology faculty or similar academic unit, may be an independent unit, or may be associated with other non-academic units as a specialist support service (Ingram, 2001; Ruane and Meijers, 2002).

Modules in languages for special purposes are generally offered in collaboration with an academic unit, such as business, law, engineering etc, where students learn a foreign language in order to support their studies in that subject or prepare for a career in the subject where they will use their foreign language. In some institutions the capacity to teach LSP is developed by the academic unit concerned, rather than by a specialist language service.

Modules in languages for academic purposes are generally offered to assist students with the language of instruction in their studies, largely irrespective of the subject. The majority of these modules are designed to teach the language of the host country to international students, but a growing number are designed to teach an international language of instruction, especially English.

Many universities offer 'lifelong language learning' modules, in which students, and academic staff, may learn a language of their choice for a wide range of purposes, including teaching and research, but also including career preparation, leisure and personal development. In many cases, these modules are open to a wide range of learners, including adults from the local community.

\section{New social and cultural context}

Universities are rooted in their host society and increasingly play a vital role in the life of the country (Corbett, 2005). As a result, higher education programmes in languages are deeply affected by the new social context that has emerged over the last three to five years. The most visible change during this period has been the international economic crisis, which continues to dominate life in every European country (Sursock and Smidt, 2010). The crisis has meant that publicly funded activities have been subject to cutbacks in almost every country. In many cases, though not all, higher education funding has been reduced, and in all cases, universities are being called upon to contribute to creating jobs and economic growth in the interests of the wider society. This is an integral aim of the Bologna process, which is aiming to give consistency and momentum to higher education (Conference of European Ministers Responsible for Higher Education, 2009).

Transnational migration has become a major feature of every European society, which includes large scale immigration from other countries in Europe and in the wider world, but also includes emigration from European countries to other areas. This tendency has transformed the language profile of most countries and has contributed to a rapid increase in linguistic and cultural diversity (Beacco and Byram, 2007; Willems, 2002). 
Higher education is at the forefront of mobility, with academic staff and students frequently working or studying away from their home country. Every university has adopted a strategy of internationalisation, seeking to attract staff and students from abroad, develop links with institutions in other countries, and raise the international ranking of the university (Knight and de Wit, 1999).

These social changes have led to significant changes in the cultural environment in which universities work. The rapid increase in the diversity of languages and cultures present in society has created a situation of 'linguistic superdiversity', in which the number of languages in contact far exceeds the ability of any individual to learn more than a fraction of the languages they might encounter (Vertovec, 2006; Creese and Blackledge, 2010).

This has produced significant shifts in the relationship between languages and cultures. Very few examples remain of a one-to-one correspondence between a language and culture. On the contrary, most cultural environments are now composed of diverse contributions from different cultural backgrounds, and are typically expressed in several languages. Where teachers attempt to teach a pure version of a language in relation to a single coherent culture, their classroom practice increasingly diverges from the experience available to learners in external reality (Risager, 2007).

At the same time as diversity is increasing, there are social and political movements to oppose it and to resist multilingualism and multiculturalism. Most European countries experience tendencies to reinforce linguistic and cultural coherence in society, often based on traditional conceptions of national identity. In some cases, this is expressed in extreme nationalist movements which reject diversity (Beer and Jacob, 1985; Baggione, 1997; Castiglione and Longman, 2007).

\section{Responding to new contexts}

All of these tendencies place particular responsibilities on language programmes to find suitable responses. Language units must take account of the changes in society in order to continue to provide valuable educational opportunities for students. On the one hand, they must offer programmes which students find relevant and attractive. On the other hand, their programmes must prepare students to function effectively in the world of work, which they will enter when they graduate. ${ }^{3}$

In the first instance, this response usually takes the form of adapting existing programmes to meet new needs. This adaptation can take many forms. It may mean including new material which addresses themes of current concern, perhaps using different texts and examples in teaching. It may mean adopting new teaching methods which better fit the students' requirements, for example

3 The discussion is informed by a series of projects undertaken by the Conseil européen pour les langues/European Language Council (CEL/ELC) between 1995 and 2007. The resulting studies and reports can be found at http://www.celelc.org/, clicking through 'Projects' and 'TNP Languages'. 
by giving greater emphasis to group work or independent learning, or introducing greater use of technological tools. It may mean introducing new organisational arrangements, such as greater participation of students in evaluation of teaching, or involvement of employers and other stakeholder in course development.

Academic units will also need to consider developing new programmes to meet the new needs. In many cases, it will be possible for a unit to learn from the good practice of other institutions locally or across Europe. In this case they can introduce new programmes which have been piloted elsewhere and appear likely to prove effective and attractive. In other cases, a unit may need to develop new programmes that respond to the specific challenges in its situation, and draw on the resources of its own expertise. In doing so, they can contribute to the stock of good practices, from which others may learn.

In any event, language units need to realise that they must 'innovate or die'. Innovation will produce new ideas and new opportunities, and is likely to be attractive to many students, who value the chance to try new things. Innovation will also tend to be viewed positively by decision-makers. If a unit is attempting to address its problems creatively, it will often be supported by senior management. Conversely, if a struggling unit refuses to contemplate change, it may risk being written off by senior management as a lost cause. ${ }^{4}$

\section{Challenges in approaches to language learning}

All European societies need to be able to communicate with people of other languages, and this has been one of the main reasons for language programmes in higher education. Language learning has traditionally been the main response to language needs. However, one of the most important challenges to language units is the fact that other approaches are emerging which may well replace much of the need for language learning.

The availability of translations has long been a vital means of communication which avoids the need for readers to understand another language. At the present time, there are many initiatives aimed at increasing the availability of translations, for example through the publishing industry, and through dubbing and subtitling of audiovisual material. Instant translations are now readily accessible on the internet. The quality of translation is quite high for the most common language pairs, and is improving for others. ${ }^{5}$

Language technology in general is progressing by leaps and bounds, and it is possible to combine voice recognition and production with machine translation to produce something close to instant interpretation. There is a large amount of

4 A range of useful resources in this area can be accessed on the website of the UK's University Council of Modern Languages (UCML) produced by the 'Shaping the future' project: http://www.ucml.ac.uk/shapingthefuture.

5 See for example: Google Translate http://translate.google.co.uk; Bing/Microsoft Translator http://www.microsofttranslator.com/; Babylon: http://translation.babylon.com/. 
military investment in this technology, and there are already implementations of it for portable devices, including mobile phones. Although this generally involves a narrow range of languages, and although the results may sometimes be inadequate, the quality and scope is increasing and the long term prospects for this technology are significant.

Intercultural communication is often presented as a valuable addition to language learning, but there is a real danger that it will be regarded as an alternative to language learning (Kelly, 2009). The argument will be that the main difficulty in communication lies not in linguistic failure but in the failure to understand cultural differences. The main tradition of intercultural communication, based in America, is constructed around the assumption that everyone will use the same language (usually English) (Jandt, 1995). Moreover, it is much easier to teach people different ideas about personal relationships, politeness, body posture or conceptions of time than to teach language competence.

The existence of a small number of lingua francas may also appear as an alternative to learning other languages. The predominance of English in many areas of life (science, business, travel etc) has led many people to assume mistakenly that 'English is enough', and that there is no reason to learn any other language (Graddol, 2006). This is compounded by the question of which other language it would be useful to learn.

Language programmes are also facing the challenge of major changes in pedagogy, which in many respects call into question traditional approaches to language teaching. Perhaps the most fundamental of these changes is the challenge to the native speaker model in language learning (Risager, 2007). For many teachers, the ultimate aspiration is to enable learners to achieve native or near-native speaker competence. However, learners (and teachers) are always conscious of their failure to achieve this. This is one of the factors in undermining motivation (Dörnyei, 2003). It is also increasingly difficult to define who is or is not a native speaker, both because there are different varieties of particular languages and because a growing number of speakers have more than one 'first' language. At the same time, it is not clear why learners should set themselves the impossible target of becoming native speakers, when they actually require a more attainable level of competence in order to function as effective communicators. And they may not wish to abandon their own cultural identity by mimicking the culture of a native speaker. However, the native speaker model is deeply rooted in traditional pedagogy and may be difficult to change.

A second challenge to traditional pedagogy is to recognise the relationships between languages and the interpenetration of one language by others. Much language pedagogy is based on target language teaching, in which learners are discouraged from using any other language in the classroom (Bhela, 1999). Moreover, teachers often use a purified version of the language, which eliminates foreign word borrowings, codeswitching and non-standard forms, which may in fact be common among native speakers. It may be challenging to take a more relaxed 
view of the interaction between languages, and even use comparison between languages as a pedagogical tool.

The inclusion of more than one language in teaching is a key element in the growing area of cognate language learning. In this approach, learners are encouraged to draw on their knowledge of one language to learn another related language. This has been particularly examined in the case of the most widely spoken language families, of Europe (Romance, Germanic, Slavonic) (Blanche-Benveniste and Valli, 1997; DGLF 2006). A development of this is the approach of intercomprehension, in which learners are encouraged to develop a passive knowledge of other languages. The aim is that learners can operate in situations where each participant speaks a language of their own choosing and understands the languages used by others. A more radical version of this approach is 'languaging', in which learners develop the ability to draw on whatever linguistic resources they and their partners may have, in order to achieve adequate communication. This typically includes code-switching, as well as a high tolerance of non-standard forms and errors (Phipps, 2006).

These new pedagogical approaches are in various degrees controversial and experimental, but are also based on finding ways of responding to the very different language requirements of contemporary societies. As yet, they remain mainly at the level of linguistic theory, and there are relatively few higher education institutions which have embraced these approaches in language teaching. But it is likely that they will become more significant if the current trends in societal multilingualism continue.

\section{Engaging with policy makers}

One of the key steps in ensuring the future development of languages in higher education is the development of institutional language policies (Beacco and Byram, 2007; Mačianskienè, 2011). These may take many forms. A formal university strategy document is useful in setting out the full range of language activities the institution supports. It is often valuable to set out specific commitments on language provision in university policy documents such as education policy, research strategy, international strategy and such like. And it will be important to ensure that languages have a place in university brochures and presentations, statements by the rector or president and various websites.

There are several elements which should be included in institutional language policies. One will be an acknowledgement that the university recognises languages as an important academic activity in its own right, with a place in the range of arts and humanities disciplines. A second will be that languages are a valuable support for the study of other disciplines, making knowledge available from a wide range of sources. And a third element will be the recognition that languages play an important role in supporting the mission of the institution. In particular, languages can play a vital role in helping students to become more employable, by providing them with valuable life skills. Languages can also play a key role in helping the institution to achieve its international ambitions, whether by providing language preparation for 
mobility of staff and students or by facilitating contacts with international partners.

In order to achieve the effective development of languages in higher education, it is important that academic staff should engage with policy makers, in order to persuade them of the importance of language (Kelly, 2003). This needs to be addressed to policy makers at a national level, such as ministers and civil servants. This is where a general framework for higher education is typically established, and where strategic priorities, funding and major initiatives are decided. Engagement also needs to be addressed at institutional policy makers, including rectors and presidents, and their deputies with particular responsibilities (education, research, international affairs). This is where the main decisions are made on implementing national policy and developing the university's own priorities.

It is important that academic staff in languages should get to know the policy makers and establish a relationship with them. ${ }^{6}$ This should be possible within the institution, but may be more difficult at national level, although in smaller countries there may be more access to national decision makers. It is useful to map out who the key decision makers are, and then work out how they may best be reached, for example by using networks of contacts and other intermediaries.

A useful form of engagement is to invite key people to high profile events. At university level, it is usually possible to invite a senior member of the management to speak at the opening of a conference or at some other formal occasion. At national level, this may be more difficult, and ways need to be found to make an event attractive to a Minister, for example by offering a suitable photo opportunity or enabling them to make an appropriate statement to a significant audience.

It will be very helpful to identify a number of champions and influencers, who are sympathetic to the importance of language and may be able to pass messages on to decision makers. They can be helpful in encouraging senior people to attend events or read briefing documents. They may make public statements of support, or they may be able to advise language academics on the most effective ways of getting their message across.

Having made contact with policy makers, it is important to engage them in effective dialogue. In the first place, it is necessary to identify their concerns and priorities. Since they are generally important people with a lot of responsibilities, they will have chosen a small number of issues to concentrate on. If they are politicians, they will typically have a small number of general themes they wish to emphasise. Once you know what the hot issues are, you can find ways of relating your message to them, so that what you are aiming to achieve seems relevant to them.

You will be aware that the discourse of policy makers is usually quite specific, and somewhat different from the way in which practising academic staff discuss things. They have their own jargon of technical terms, abbreviations and code words. It is important that you should learn their language in this sense, so that

6 Useful materials are contained on the website of the LLAS 'Thriving in difficult times' workshop (2009): http://www.llas.ac.uk/events/archive/3258. 
you give your message in a way that they can readily understand it and consider it reasonable in the terms they are used to discussing.

Since policy makers are busy people, they will generally not wish to spend a lot of time in puzzling out the nature of a problem or what they ought to do about it. If you are to make good use of your access to them, there are two requirements. First, you should formulate your own problems in terms which they can easily understand. If possible present them in such a way that they appear as a problem for the policy maker, who will then have a motivation for responding. Second, you should offer a solution to the problem, in terms which they can understand. You should make sure that what you are proposing will actually offer a solution, and that it is within the remit of the policy maker to do it. It is a further advantage if they are then happy to adopt this course of action as their own solution. (Do not quibble over who thought of it.)

And finally, try to ensure that your key message is conveyed by as many other voices as possible. On the one hand, involving a wide range of colleagues is likely to build a greater consensus and enthusiasm. On the other hand, policy makers will give greater weight to a message that they hear from a number of different quarters.

\section{Conclusion}

Languages are vitally affected by far-reaching changes currently taking place in Europe. The situation provides major challenges to the way we think about ourselves and the way we work. But it also offers important opportunities if we can mobilise the flexibility of mind, the creativity and the organisational skills which are typically found in the academic community in the area of languages. The key to achieving this is undoubtedly through collaboration, which will enable us to share our knowledge and expertise, to spread new ideas and practices and to work together in pursuit of our shared aspirations.

\section{References}

Baggione, D. (1997). Langues et nations en Europe. Paris: Payot.

Beacco, J. C., \& Byram, M. (2007). From Linguistic Diversity to Plurilingual Education: Guide for the Development of Language Education Policies in Europe. Strasbourg: Council of Europe.

Beer, W. R., \& James, J. E. (1985). Language policy and national unity. Totowa, NJ: Rowman \& Allanheld.

Bhela, B. (1999). «Native language interference in learning a second language: Exploratory case studies of native language interference with target language usage.» International Education Journal no. 1(1), 22-31.

Blanche-Benveniste, C., \& Valli, A. (1997). L'intercompréhension: le cas des langues romanes. $N^{\circ}$ spécial Le Français dans le monde.

Buttjes, D., \& Byram, M. (1991). Mediating Languages and Cultures: Towards an intercultural theory of foreign language education. Clevedon: Multilingual Matters.

Castiglione, D., \& Longman, C. (2007). The language question in Europe and diverse 
societies: political, legal and social perspectives. Portland, OR: Hart.

Conference of European Ministers Responsible for Higher Education. 2009. The Bologna Process 2020 - The European Higher Education Area in the new decade. Conference of European Ministers Responsible for Higher Education. Retrieved from http://www.ond.vlaanderen.be/hogeronderwijs/bologna/conference/documents/ Leuven_Louvain-la-Neuve_Communiqu\%C3\%A9_April_2009.pdf.

Corbett, A. (2005). Universities and the Europe of knowledge: ideas, institutions and policy entrepreneurship in European Union higher education policy, 1955-2005. Basingstoke Palgrave Macmillan.

Creese, A., \& Blackledge, A. (2010). «Towards a sociolinguistics of superdiversity.» Zeitschrift für Erziehungswissenschaft, 13 (4).

DGLF (2006). L'intercompréhension entre langues apparentées, Délégation générale à la langue française et aux langues de France. Paris: Ministère de la Culture et de la communication.

Dörnyei, Z. (2003). Attitudes, Orientations, and Motivations in Language Learning: Advances in Theory, Research, and Applications. Oxford: Wiley-Blackwell.

Evans, C. (1988). Language People: the experience of teaching and learning modern languages in British universities. Milton Keynes: Open University Press \& Society for Research into Higher Education.

- - (1990). «A Cultural view of the discipline of Modern Languages.» European Journal of Education, 25(3), 273-282.

Forbes, J., \& Kelly, M. (1995). French Cultural Studies: an Introduction. Oxford: Oxford University Press.

Graddol, D. (2006). English Next. London: British Council.

Hinkel, E. (1999). Culture in second language teaching and learning, Cambridge Applied Linguistics. Cambridge: Cambridge University Press.

Ingram, D. (2001). Language Centres: Their Roles, Functions, and Management. Vol. John Benjamins: Amsterdam.

Jandt, F. E. (1995). Intercultural Communication: An Introduction. Thousand Oaks: Sage.

Kelly, M. (2003). «Les Mains sales: Engaging with policy for languages in higher education.» In D. Head, E. Jones, M. Kelly and T. Tinsley (Ed.), Setting the Agenda for Languages in Higher Education (pp. 101-116). London: CILT.

-- (2009). A third space for Europe: Intercultural communication in European language policy. European Journal of Language Policy / Revue européenne de politique linguistique, 1(1), 1-20.

Kelly, M., Grenfell, M., \& Jones, D. (2003). The European Language Teacher. Bern: Peter Lang.

Knight, J., \& de Wit, H. (1999). Quality and Internationalisation in Higher Education. Paris: Organisation for Economic Co-Operation and Development (OECD).

Kramsch, C. (2004). «Language, thought and culture.» In A. Davies and C. Elder (Ed.), The Handbook of Applied Linguistics, (pp. 235-261). Malden, MA: Blackwell.

Mačianskienè, N. (2011). «Developing Institutional Language Policy.» Santalka: Filologija, Edukologija, 19 (2), 158-167.

Phipps, A., \& Gonzalez, M. (2004). Modern Languages. Learning and Teaching in an Intercultural Field. London: Sage.

Phipps, A. M. (2006). Learning the Arts of Linguistic Survival: Languaging, Tourism, Life. Clevedon: Channel View. 
Richards, J. C., \& Nunan, D. (1990). Second language teacher education. Cambridge: Cambridge University Press.

Risager, K. (2006). Language and culture: Global flows and local complexity. Clevedon: Multilingual Matters.

--- (2007). Language and Culture Pedagogy: From a National to a Transnational Paradigm. Clevedon: Multilingual Matters.

Roditi, E. (1982). Interpreting: Its History in a Nutshell. Washington DC: National Resource Center of Translation and Interpretation, Georgetown University.

Ruane, M., \& Meijers, G. (2002). Language Centres: The Promotion of Quality in Language Learning: Papers from the 6th CERCLES Conference, Antwerp, 14-16 September 2000. Antwerp: CERCLES.

Sursock, A., \& Smidt, H. (2010). Trends 2010: A decade of change in European Higher Education. Brussels: EUA Publications.

Towell, R. (1998). «Languages in Higher Education.» In Moys A. (Ed.), Where are we going with languages?, (pp. 44-53). London: Nuffield Foundation.

Vertovec, S. (2006). «The Emergence of Super-Diversity in Britain.» Centre on Migration, Policy and Society, Oxford, Working Papers, 25.

Willems, G. M. (2002). Guide for the development of Language Education Policies in Europe - From Linguistic Diversity to Plurilingual Education: Reference Study. Strasbourg: Council of Europe.

Zhu, W., Seedhouse, P., Wei, L., \& Cook, V. (2007). Language Learning and Teaching as Social Interaction. London: Palgrave Macmillan.

\section{Michael KELLY}

Pietu Hemptono universitetas

\section{KALBU POLITIKA AUKŠTAJAME MOKSLE}

Santrauka. Aukštasis mokslas Europoje, kaip ir visame pasaulyje, išgyvena ypatingu ir labai svarbiu pokyčiu laikotarpi. Socialiniai ir politiniai pokyčiai neišvengiamai paliečia ir kalbu programas. Šios programos pastaruoju metu ne tik plètoja kalbinę kompetencija (dažnai bent dvieju užsienio kalbu), bet ir pateikia detaliu tyrimu apie visuomenès aspektus - socialinę ir politinę struktūrą ar verslo aplinką. Kiekvienas universitetas Europoje igyvendina tarptautiškumo strategijas, kuriomis siekia pritraukti studentu ir darbuotoju iš užsienio šaliu, užmegzti ryšius su institucijomis kitose šalyse ir kelti universitetu tarptautiškumo lygi. Pabrèžtina, kad mainai vyksta ne tik tarp Europos universitetu, bet plètojami ryšiai ir tarp Azijos bei Amerikos aukštojo mokslo instituciju. Tai suteikia daug galimybiu, tačiau esama ir rimtu pavoju, apie kuriuos būtina kalbèti bei ieškoti problemu sprendimo būdu. Asmenys, kuriantys kalbu politiką, būdami užsièmę dažnai nenori labiau issigilinti i problemos esmę ir nuo ju priklausančius galimus sprendimus. Šio straipsnio tikslas - išanalizuoti keleta svarbiausiu Europos aukštojo mokslo kalbu politikos problemu ir pasiūlyti galimus praktinius ju sprendimo būdus. Norint efektyviai plètoti kalbinę kompetencija aukštajame moksle, svarbu, kad akademinès bendruomenès darbuotojai prisidètu prie kalbu politiką kuriančiu asmenu ir itikintu juos, jog kalbu mokymas(is) yra svarbus. Kalbu svarba turètu būti akcentuojama nacionaliniu lygiu, bendraujant su ministerijomis ir valstybès tarnautojais.

Pagrindinès sąvokos: aukštasis mokslas, kalbu politikos problemos, programos. 